DOI 10.4467/25439561KSR.21.008.14419

ИринА ВороНЦОВА* (D) https://orcid.org/0000-0002-0272-6513

Православный Свято-Тихоновский гуманитарный университет Москва

\title{
АНТОН КАРТАШЕВ В ГОДЫ РЕЛИГИОЗНОГО ДВИЖЕНИЯ ЗА ЦЕРКОВНУЮ РЕФОРМУ В РОССИИ
}

\section{ANTON KARTASHEV AND HIS PARTICIPATION IN THE RELIGIOUS MOVEMENT SUPPORTING CHURCH REFORM IN RUSSIA}

\section{Резюме}

В начале XX в. в России возникло религиозное движение интеллигенции за церковную реформу. Толчок ему дало Новое религиозное сознание (НРС), в центре которого было учение неохристиан о единстве духа и плоти, «небесного» и «земного», его метафизика декларировала новые включения в христианскую догматику, призывала к воцерковлению продукта психофизической и культурной жизнедеятельности человека. Начинающий церковный историк А.В. Карташев увлекся новым религиозным сознанием и вскоре стал одним из лидеров движения. Этот период его жизни известен менее всего. Статья рассказывает о мировоззрении Карташева в 1901-1916 гг. и систематизирует сведения о его общественной деятельности. Автор приходит к выводу, что у Карташева был свой взгляд на догму Нового религиозного сознания и своя позиция по церковной реформе.

\section{Abstract}

At the beginning of the $\mathrm{XX}^{\text {th }}$ century, a religious movement initiated by intelligentsia supporting Church reform emerged in Russia. It was triggered by The New Religious Consciousness (NRC), in the center of which there was teaching of neo-Christians about the

* Irina Woroncowa, Prawosławny Uniwersytet Humanistyczny im. św. Tichona, Moskwa 
unity of spirit and flesh, "the heavenly" and "the earthly". Its metaphysics declared new additions to Christian dogma, called for spiritualising the outcomes of psychophysical and cultural endeavours of a person. A.V. Kartashev, a novice Church historian, got interested in The New Religious Consciousness and soon became one of the movement's leaders. This period of his life is the least known. The article presents Kartashev's viewpoint of 1901-1916 and systematises information about his public actions. The author comes to the conclusion that Kartashev held his own view on The New Religious Consciousness dogma and his own opinion on Church reform.

Ключевые слова: Антон Владимирович Карташев, религиозная реформа, неохристианство, церковная реформа в России, XX век.

Keywords: Anton V. Kartashev, religious reform, neo-Christianity, Church reform in Russia, $20^{\text {th }}$ century.

Общественный деятель и церковный историк А.В. Карташев до сих пор остается одним из малоизвестных деятелей религиозного ренессанса в России начала XX в. Те немногие ученые, которые интересовались им, отзываются о Карташеве как о культурном деятеле, интеллектуальные интересы которого концентрировались вокруг «новой симфонии» Церкви и государства ${ }^{1}$. О нем пишут как о талантливом церковном историке, исследования его интеллектуальной биографии, как правило, относятся к периоду расцвета его таланта ${ }^{2}$. Путь Карташева в неохристианстве (1900-1906) - это отдельный и малоизвестный этап, который сложно совместить с началом его карьеры - доцента духовной академии, и с ее вершиной - на посту министра вероисповеданий Временного правительства (1917). Начало его парадоксальной биографии все еще остается «белым пятном», и проблема ${ }^{3}$ зависит от глубины погружения исследователя в доктрину и вербальную систему Нового религиозного сознания (HРC) и религиозного движения за реформу. Наше обращение к заявленной

${ }^{1}$ А.В. Антощенко, «Евразия» или «Святая Русь»? Российские эмигрантыл «первой волны»» в поисках исторического самосознания: дисс. д-ра ист. наук, Санкт-Петербург, С.-Петербургский государственный университет, 2004.

${ }^{2}$ А.Л. Золаев, Исторические воззрения А. В. Карташева и историография русского зарубежья: дисс. канд. ист. наук, Москва, Российский университет дружбы народов, 2005; А.А. Пешков, Философия истории П.Н. Милюкова и А.В. Картамева: сравнительный анализ: дисс. канд. филос. наук, Нижний Новгород, Нижегородский государственный педагогический университет, 2014, С.П. Бычков, «Очерки по истории русской церкви» А.В. Карташева в оиенке современников, [в:] Омские научные чтения 2020: Материаль Четвертой Всероссийской научной конференции, Омск, Омский государственный университет им. Ф.М. Достоевского, 2020, сс. 12981303.

С.П. Бычков, О проблемах исследования первого периода жизни русского иерковного историка А.В. Карташева, «Вестник Омского университета» 2018, № 3 (19), сс. 228-233. 
теме основано на многолетнем изучении доктрины и идеологии движения ${ }^{4}$, эпистолярного наследия Карташева начала XX в.

\section{Начало жизненного пути}

Антон Владимирович (11.06.1875-10.09.1960) родился в семье горнозаводских рабочих. В детстве он пел на клиросе, в 8 лет был посвящен в стихарь; в 1888 г. закончил церковное училище, в 1894 г. с отличием - Пермскую духовную семинарию, и его отправили учиться на казенный счет в Санкт-Петербургскую духовную академию (СПбДА). Здесь он стал учеником профессора протоиерея П.Ф. Николаевского, историка и собирателя древних рукописей, критика устоявшихся мнений. Для выпускной работы Карташев выбрал тему, которая говорит о его раннем влечении к художественному слову - Жизнь и творения св. Иоанна Златоуста в древне-славяно-русской письменности. В 1899 г. он был оставлен при академии как профессорский стипендиат; его рассматривали как преемника заведующего кафедрой П.Ф. Николаевского. Однако митрополит Санкт-Петербургский Антоний (Вадковский) не утвердил решение Ученого совета. Карташеву предложили заняться малоизученным синодальным периодом русской церковной истории, но его не влекла работа с документами, он изучил наиболее важные курсы церковной истории, став одним из первых церковных историографов. В 1900 г. он предложил свой лекционный курс и в сентябре его утвердили на должности исполняющего обязанности доцента кафедры церковной истории, а в 1903 г. его лекции опубликовали в академическом журнале 5 . Академический устав (1884) требовал, чтобы Карташев в течение двух лет защитил магистерскую диссертацию. Он выбрал тему История Санкт-Петербургской духовной академии. Часть первая (период подготовительный и начальные годы существования академии), но работать над ней не стал, в архиве СПбДА нет записей о затребовании Карташевым каких-либо исторических документов. За 5 лет под его научным руководством начали писать диссертации 12 студентов, но большинство ушло от него на ка-

${ }^{4}$ И.В. Воронцова, Русская религиозно-философская мысль в начале ХХ века, Москва, Издательство Православного Свято-Тихоновского гуманитарного университета, 2008, 424 сс.; ее же, Революичия и религия в дискуссии 1906-1914 годов Д.С. Мережковского, Н.А. Бердяева и П.Б. Струве и других, «Религиоведение» 2011, № 4, сс. 28-39; ее же, Тематика статей А.В. Карташева в газете «Страна» 1906-1907 г2. в свете программных аспектов движения религиозной интеллигенции за иеековную реформу, «Вестник Православного Свято-Тихоновского гуманитарного университета» 2019 (II), № 5-6, сс. 11-24 и др.

${ }_{5}^{5}$ А.В. Карташев, Краткий историко-критический очерк систематической обработки русской иеерковной истории, «Христианское чтение» 1903, № 6, сс. 909-922; № 7, сс. 77-93. 
федру гражданской истории. Если отследить по годам (1901-1905) уменьшение числа его студентов, то оно прямо пропорционально погружению Антона Владимировича в новую для него среду религиозной интеллигенции.

\section{Между Русской Церковью и неохристианством}

Как профессор Санкт-петербургской духовной академии Карташев принял участие в Петербургских религиозно-философских собраниях (ПРФС, 19011903). Здесь он сблизился с неохристианским кружком Д.С. Мережковского. Попав из церковно-академической среды в круг писателей, поэтов, художников, журналистов, 26-летний доцент духовной академии не без интереса наблюдал свободу религиозного поиска околоцерковной и внецерковной интеллигенции, ее творческую активность, а на заседаниях ПРФС - схоластическую скованность тех, кто должен был эту интеллигенцию наставлять. Карташев заинтересовался идеей догматического развития, учением неохристиан о новых откровениях и новом религиозном сознании для христианской церкви, проникся «пророческим служением» России. Также с 1902 г. Карташев бывал в Христианском содружестве молодежи, где будущие церковные реформаторы - священники В.Я. Колачев и К.М. Аггеев - обсуждали замену церковной схоластики «живой проповедью», а в 1904 г. заговорили о необходимости переформулирования догматов и пересмотре отношения к духовному старчеству.

Проводником в неохристианство для Карташева стал В.В. Розанов. Его отношение к России - Святой Руси импонировало Карташеву, он написал Розанову письмо, в котором высказал восхищение тем, как Розанов видит этнокультурный образ России ${ }^{6}$. Эстетическое отношение к церковной культуре православия сблизило их:

«Я часто восхищаюсь психологической и эстетически жизнерадостной тонкостью многих из ваших новейших писаний [...] и не раз порывался признаться вам в этом письменно, но сковывающая меня дисциплинарность [...] обычно сдерживала мои порывы. Теперь же не хочу терпеть... ${ }^{7}$ мож[ет] б[ыть] потому, что задета глубочайшая почва моих основных, кровных и давно мной сознанных идеалистических симпатий и антипатий...»

${ }^{6}$ Письмо А.В. Карташева В.В. Розанову от 5 марта 1903 г., Российский государственный архив литературы и искусства (далее - РГАЛИ). Ф. 419, оп. 1, ед. хр. 482, л. 1.

${ }^{7}$ Многоточие Карташева.

${ }^{8}$ Письмо А.В. Карташева В.В. Розанову от 5 марта 1903 г. РГАЛИ. Ф. 419, оп. 1, ед. хр. 482, л. 1-1 об. 
С 1902 г. Карташев стал завсегдатаем розановских «чаепитий», где царило поощрение литературного и религиозного творчества. Со всей очевидностью можно сказать, что это была та атмосфера, которой не хватало порывистой и эмоциональной натуре молодого доцента.

«Мы охвачены принципом влюбленности в мир, влюбленность - единственное притяжение для нас в религии, - писал Карташев Г.И. Чулкову. - Все другое - в большей или меньшей степени случайность»9.

Розанов, в начале $\mathrm{XX}$ в. воспринимавшийся неохристианами в ореоле учителя, возымел влияние и на молодого историка, Карташев признался ему, что не рассматривает всерьез свои занятия историей:

«я русскую историю никогда не любил и никогда, конечно, не полюблю. [...] Я еще не прилагал своих сил к предмету любви, да и не нащупал еще его окончательно. А хочется найти, служить и „пророчествовать“” ${ }^{10}$.

С апреля 1902 г. под председательством Карташева в ПРФС обсудили несколько предложенных интеллигенцией тем: «свобода совести», «сила и насилие в христианстве», «Лев Толстой и Русская Церковь». Карташева интересовала реакция Церкви на учение Л.Н. Толстого, отлучение писателя Антон Владимирович рассматривал не иначе как следствие несвободы Русской Церкви от самодержавия и подчеркивал важность поиска «нормального соотношения светской власти и церкви» ${ }^{11}$. Когда в ПРФС был поставлен вопрос о применении государством силы в вероисповедной области, Карташев подчеркнул, что нарушена несовместимость природы Церкви и государства ${ }^{12}$. Как председатель, он откорректировал выводы Собраний по двум вопросам: можно ли Церкви одобрять меры государственного насилия и полезны ли для Церкви такие меры, и остановился на том, что существует соблазн признать мысль о религиозном насилии законной и священной необходимостью ${ }^{13}$. Так, уже в ПРФС он занял позицию церковного либерала. В 1902 г. он склонялся к поддержке неохристиан: например, поддержал позицию Мережковского в прениях по докладу (Гоголь

${ }^{9}$ Письмо А.В. Карташева Г.И. Чулкову от 17 мая 1905 г., РГАЛИ. Ф. 548, оп. 3, ед. хр. 13, л. 1.

${ }^{10}$ Письмо А.В. Карташева В.В. Розанову от 5 марта 1903 г., РГАЛИ. Ф. 419, оп. 1, ед. хр. 482, л. 1.

11 Записки Петербургских религиозно-философских собраний (1901-1903 г2.), общ. ред. С.М. Половинкин, Москва, Республика, 2005, с. 70.

12 Там же, с. 138.

${ }^{13}$ Там же, с. 172. 
u о. Матвей), где была заявлена проблема «духа и плоти» в христианстве ${ }^{14} ;$ в прениях о «браке в христианстве» он тоже поддержал Розанова в его мнении о том, что учение Церкви о «предпочтении девства - браку» «не раскрыто и взгляд на брак как будто не уяснен $\rangle^{15}$. Проникшись расположением к Розанову, Карташев был готов читать вместо него доклады в ПРФС, но этого не разрешил официальный председатель Собраний епископ Ямбургский Сергий (Страгородский).

Карташев согласился с заявлением религиозной интеллигенции, что культуру нужно освятить. В 1902 г. он был одним из немногих участников ПРФС с церковной стороны, кто разобрался в том, что формула «освятить культуру» означала в НРС оправдание церковью «плоти», т.е. всех творческих, физических (психических, физиологических) проявлений жизнедеятельности человека через распространение на них принципа халкидонского догмата (принят Вселенским собором 451 г. в отношении Богочеловека Христа). Большинство считало, что речь идет об освящении произведений искусства.

Карташев стал сотрудничать с журналом неохристиан «Новый путь»: под псевдонимом Романский он отвечал на критику НРС. Вскоре им была написана статья, которая показала, что церковный историк не просто поддержал неохристианство, но и осмыслил его концепты и приобрел свой взгляд на теорию НРС о святости плоти. Так в 1903 г. он стал участником движения, которое родилось как противостояние утилитаризму народнической мысли и марксистской идеологии, вошло неотъемлемой частью в русский религиозный ренессанс начала XX в., но сконцентрировалось на церковной реформе и утверждении мира материального как первейшего элемента духовной жизни.

Несмотря на идейное сближение с неохристианами, Карташев продолжал выступать в ПРФС от лица Русской Церкви, печатался в журналах движения. В 1905 г. епископ Сергий (Страгородский) предложил ему сделать выбор, и Карташев ушел из академии. В конце 1905 г. Мережковский, Гиппиус и Философов уехали за границу и на попечение Карташева оставили сестер Гиппиус. Так в 1905 г. он вошел во вторую после супругов Мережковских и Философова неохристианскую «троицу» ${ }^{16}$, и стал жить на две «семьи»- заботился об отце и подраставшей сестре Лизе и о Т.Н. и Н.Н. Гиппиус, составивших вместе с ним религиозную общину.

Новая жизнь воодушевила Карташева: он посещал православную церковь, привлекал к этому членов своей «троицы» и соглашался на молитвенные собрания внутри своей «церкви». В письме в Париж от 19 марта 1906 г. он сообщал

${ }^{14}$ Там же, сc. 203-204.

15 Там же, сc. 244-245.

${ }^{16}$ «Троицы» представляли собой религиозную ячейку неохристиан, жившую своим кругом и совершавшую молитвенные собрания. 
3.Н. Гиппиус: «И в Субботу до церкви соберемся сначала сами» ${ }^{17}$, но «пока мало своего» (своих молитв и обрядов, - И.В.). В предпасхальную неделю, служили тоже сами: «Мы готовились к Четвергу и к Воскресенью. Уже план готов. Я с любовью уделял этому время. И с радостью думаю, как будет выполнено. От этого великая радость. Почти счастье ${ }^{18} »,-$ писал он 27 марта 1906 г. 11 мая он сообщал, что церковный праздник Вознесения встретили «по-своему» ${ }^{19}$. Судя по текстам его писем в Париж, он жил размышлениями о новом откровении и необходимости прогресса в церковном учении:

«шёл по темным улицам из типографии и понял ясно ${ }^{20}$ необходимость, право и свободу для церкви развиваться, идти к новым откровениям, переливаться в апокалипсис, не ожидая, когда поймут „епископы“ $[. .$.$] Ну, словом, как-то умственно$ аргументировал для себя ясно то, чем живу фактически, как императивом новой религии» ${ }^{21}$.

В 1906 г. Карташев получил место профессора Бестужевских Высших женских курсов и должность библиографа в Публичной библиотеке, что дало ему возможность заняться научной работой. Вскоре необходимость трудиться на двух должностях сказалась в физическом утомлении, к тому же ему приходилось регулярно писать Мережковским о том, как идет его погружение в «религиозный вопрос» и обсуждать отношения с Татьяной Николаевной Гиппиус. Личное чувство к ней, все более и более подпадавшей под влияние 3.Н. Гиппиус, заставляло его страдать из-за невозможности создать семью.

В духовном плане Карташев испытывал то радость ${ }^{22}$, то отчаяние: супруги Мережковские не принимали его мысли о том, что задуманная ими «новая церковь» невозможна без преемства с Церковью исторической. Карташев, привязанный к обрядовости православных служб особой, вынесенной из детства любовью, сохранял веру в реформированную Церковь. На 1906-1907 гг. пришлась полемическая переписка Карташева с Д.С. и З.Н. Мережковскими и Философовым, которым он пытался объяснить свою мысль о преемстве (Тело Христово, писал он, уже было «соткано» в истории и существует в христианской Церкви, и метафизически невозможно создание еще одного Тела ${ }^{23}$ ).

${ }_{17}$ T. Pachmuss, Intellect and Ideas in Action: Selected Correspondence of Zinaida Hippius, München, Fink, 1972, c. 649.

${ }_{18}$ Там же, с. 651.

${ }^{19}$ Там же.

20 Здесь и далее курсив Карташева.

${ }^{21}$ T. Pachmuss., Intellect and Ideas..., указ. соч., с. 655.

22 Там же, с. 657.

${ }^{23}$ Там же, с. 702. 
Август 1906 г. Карташев провел в родном Екатеринбурге, с отцом и сестрой, проживая на территории Ново-Тихвинского монастыря. Внутренний конфликт поставил Карташева перед выбором, и он задавался вопросом: «покориться» учению Церкви и уйти в монастырь, отказавшись от борьбы за освящение культуры и новую общественность, «или удержать за собой право жизни, и уже тогда» стать «врагом церкви и христианства» ${ }^{24}$. Он считал, что, оставшись верным церковной традиции, он лишится «живого мира, свободной общественности, русской революции, социализма, культуры» ${ }^{25}$. Также для него равно было неприемлемо присущее лидерам религиозного движения бездеятельное философствование о будущем христианстве. Выбор срединного пути ставил его в условия, когда в 1907 г. он оказался чужим среди «своих», т.е. неохристиан, и своим для церковных реформаторов, которые были для него «чужими». Интеллигенция не предпринимала практических мер к продвижению реформы, но и реформаторы, хотя и внедрялись в сферу общественной жизни, не в силах были сдвинуть с места вопрос религиозной реформы, так как сами были представителями Церкви. А Карташев томился по деятельному служению.

«Меня томит желание фактической [...] связи с человечеством, с общественностью, с культурным строительством, желание конкретной [...] работы [...] с осязательными результатами, с радостными улыбками обрадованных мною лиц» ${ }^{26}$.

Занятие журналистикой дало Карташеву возможность вынести на страницы печати свои думы и отношение к пассивной позиции Русской Церкви в годы первой русской революции. В 1908 г. в лице секретаря Петербургского (Петроградского) Религиозно-философского общества (ПРФО) (1907-1916) он встретил единомышленника: С.П. Каблуков был человеком церковным, цельным по убеждениям, но тоже увлекшимся идеей религиозной реформы. Третьим в их кругу стал литератор В.И. Иванов. Как и Карташев, Иванов (в 1906) предпочел историческую Церковь, принимал церковные догматы и считал неправильным прекращение евхаристического общения с Русской Церковью, писал, что признает церковную иерархию и «императив соборного действия» ${ }^{27}$ и не принимает идею Мережковского о соединении политического строительства будущей России с религиозной реформой. Взгляды Карташева и Иванова и их доверие

${ }^{24}$ Там же, с. 686.

${ }^{25}$ Там же, с. 678.

${ }^{26}$ Там же, с. 674.

${ }^{27}$ Из письма В. И. Иванова Д.С. Мережковскому от 28.XI.<19>08, цит. по: М. ЦимборскаЛебода, Н.А. Богомолов, К проблеме «Мережковский и Вячеслав Иванов», [в:] Studia Rossica VII. W kraju i na obczyźnie. Literatura rosyjska XX wieku, ред. W. Skrunda, Warszawa, Wydawnictwo «Studia Rossica», 1999, c. 86. 
исторической Церкви ${ }^{28}$ отличали их представление о «воцерковлении» культуры от мнений мережковского кружка. Долгие годы Карташев не оставлял попыток убедить остальных неохристиан (супругов Мережковских, Философова, В.П. Кузнецова, С.П. Ремизову, А.А. Мейера и К.А. Половцеву) и «мистического анархиста» Г.И. Чулкова восстановить общение с исторической Церковью.

Став профессором Высших женских Бестужевских курсов, Антон Владимирович пришел к решению, что и здесь возможно продвигать «общее дело». Он написал супругам Мережковским, что намерен входить в соприкосновение с общественностью на базе своей профессиональной пригодности. Исполняя обязанности заведующего отделом Императорской публичной библиотеки, где он комплектовал церковно-богословскую литературу, Карташев вернулся к церковной истории. Он подготовил две статьи для журнала СПбДА ${ }^{29}$. Содержание их говорит о том, что он обработал ряд исторических документов и изложил свое личное мнение. В статьях мы видим подчеркнуто свободное отношение к церковной традиции, указание на мифологизацию событий. Сомнения о том, что апостол Андрей проповедовал на Руси, Карташев и ранее высказывал в печати, в 1907 г. он вернул внимание общественности к этому вопросу, заняв позицию критика церковного предания. Вторая статья, написанная через год (Христианство на Руси в период догосударственный), представила научное описание «начатков» христианства в Скифии до IV в., встречающееся в историографии первых веков христианства, и исследование позднейшего распространения его в Крыму. Карташев ставил задачу прояснить время прихода христианства на территорию Руси и одновременно рассматривал вопрос «Откуда пошла есть Русская земля?». Это исследование опиралось на значительное количество греческих, южнорусских и германских летописных источников, его этнографические моменты позволяют предположить, что в эти годы им создавался задел для позднейших исторических трудов.

Возможно, что вторая статья имела еще одно значение: определившись с вопросом о том, в каком отношении вселенская Церковь находится к историческому православию, Карташев подкрепил ею свои утверждения о том, что предполагаемая неохристианами «новая церковь» или церковь апокалиптических времен не может не быть в преемственной связи с Церковью исторической. Но, по Карташеву, синодальная Русская Церковь на тот момент искомому

${ }^{28}$ Письмо А.В. Карташева В.И. Иванову от 7 апреля 1911 г., Научно-исследовательский отдел рукописей Российской государственной библиотеки (НИОР РГБ). Ф. 109, к. 27, ед. хр. 20, л. 1-2, 3-4 об.

${ }^{29}$ А.В. Карташев, Был ли апостол Андрей на Руси?, «Христианское чтение» 1907, № 6, сс. 83-95; его же, Христианство на Руси в период догосударственный, «Христианское чтение» 1908, № 5, cc. 763-778. 
образу церкви будущего не соответствовала. Занятая им позиция либерального церковного историка показывает, что в 1906-1908 гг. он преодолевал личный кризис, вызванный намерением пройти между «Сциллой и Харибдой» - интеллектуальным влечением к неохристианству и привязанностью к богослужебной культуре православной Русской Церкви.

\section{А. Карташев как религиозный мыслитель}

Системно философия «нового религиозного сознания» и церковной реформы в России представлена Карташевым в статье 1903 г. $^{30}$, двух речах в ПРФО и в трактате Реформа, реформацияиисполнение Церкви. Если для Мережковского в догме НРС был важен концепт «троичности» и Третий Завет, для Розанова пол и брак в христианстве, а Н.М. Минский считал, что Бога следует искать, опираясь на присущий человеку инстинкт познания и «двуединство» добра и зла, то Карташев хотел видеть высший замысел во всем, что сотворено божественным актом. Его апология единства духа и плоти предлагала теологию «плоти» как вечной субстанции, изначально и навеки соединенной с миром духовным $^{31}$, занимающей в судьбах человечества важное место. Он считал, что Боговоплощение навеки «фиксировало плоть во всех ее существенных свойствах и освятило все то специфическое, что она вносит в водоворот человеческого бытия» ${ }^{32}$. Антон Владимирович считал, что Бог не мог сотворить ничего случайного и незначительного.

«Все второстепенное, служебное, инструментальное, преходящее, должно быть по этому самому - и случайным, и акциденциальным, т.е. рождаться из процесса, из комбинаций уже существующего бытия, между тем, материя или полнее, „плоть“, есть вовсе не акциденция, а несомненно - первоосновной, первозданный атрибут космоса; а ее первозданность с логической необходимостью требует признать и ее финальную самоценность: ее самостоятельное участие в последних целях бытия» ${ }^{33}$.

Не упоминая о церковном учении сотворения мира «из ничего», он писал: «Что такое материя, плоть, тело, вообще космос? Если взглянуть на мир даже без малейшего оттенка пантеизма, и то мы должны признать, что плоть есть такой же вечный принцип космического бытия, как и дух. [...] Допустимо ли при таком

\footnotetext{
${ }^{30}$ Т. Романский, Не все же, «Новый путь» 1903, № 6, сс. 262-276.

${ }^{31}$ Там же, сc. 270-271.

${ }^{32}$ Там же, с. 273.

${ }^{33}$ Там же, сc. 271-272.
} 
равновеликом качестве духа и плоти в строе бытия, предположение о назначении одного начала быть ,лишь органом“ другого?» ${ }^{34}$.

«Предположение», упомянутое Карташевым, это мнение святых отцов и учителей Церкви о плоти как инструменте человеческого духа. «Мы ${ }^{35}$ не принимаем тезиса: тело есть лишь орган духа» ${ }^{36}$, это «лишь» не выдерживает критики ни по метафизическим, ни по религиозным соображениям, «мы не полагаем в основание всей этой концепции традиционной метафизики» ${ }^{37}$.

Он считал, что христианское отношение к «плоти» «недостаточно мотивирует творческий акт создания материи; не уясняет таинственного факта навечной связанности духа с плотью» ${ }^{38}$.

«Все тварное будет вечно жить в сложной или плотской форме существования. Если бы идеалом лично-разумной жизни были чистейшие состояния духа, то к чему тогда творческая воля облекла это начало какой-то стеснительной оболочкой, каким-то плохим, обременительным оружием, отделаться от которого... составляет в конце концов желанную цель? [...] Ведь и в вечности мы остаемся с теми же телами $[\ldots]$, это не будет застывшее созерцание одного духа, но та же, известная нам по опыту, хотя и утонченная, волнующаяся смена живых потребностей, непрерывная цепь стремлений, усилий, достижений, успокоений, наслаждений и обратных состояний» ${ }^{39}$.

Венчало его апологию плоти убеждение в том, что «таинство соединения с плотью Самого Божества» не может оставаться в философском пренебрежении: «плоть имеет пред собой те же вечные перспективы и цели, как и дух» ${ }^{40}$. «Одинаковые права на привилегированное положение в царстве вечности» ${ }^{41}$ утверждались Карташевым на примере церковной Евхаристии, значение которой он традиционно считал возможностью обожения. Вследствие Боговоплощения «человечество есть богочеловеческая плоть, есть тело Христово"42. Это Тело «соткалось в истории», стало Церковью, и потому культура религиозной

\footnotetext{
${ }^{34}$ Там же, сc. 270-271.

${ }^{35}$ Карташев писал это от имени неохристиан.

${ }^{36}$ Ср.: Святитель Феофан Затворник Вышенский, Начертание христианского нравоучения, Москва, Лепта Книга, 2003, с. 326.

${ }^{37}$ Т. Романский, Не все же..., указ. соч., с. 271.

${ }^{38}$ Там же.

${ }^{39}$ Там же, с. 272.

40 Там же, 273.

${ }^{41}$ Там же, сс. 274-275.

42 Религиозно-философское общество в Санкт-Петербурге (Петрограде): История в материалах и документах. 1907-1917, в 3 тm., т. 3, Москва, Русский путь, 2009, с. 175.
} 
общественности, или «плоть мира», для Карташева была достойна акта освящения. «Ибо только в церкви постигается и осуществляется метафизически религиозное соотношение Божества с космосом, с жизнью, с человеческим обществом, с социально-экономическим строем, соотношение Бога с плотью» ${ }^{43}$.

Карташев считал, что в христианстве существует «догмат» о Царстве Божием с «особой метафизикой» совмещения «неприятия мира с его приятием», взаимоотношением «религиозного духа, христианской святости... благочестия к плоти мира и человеческой жизни» ${ }^{44}$. (Для Карташева это метафизика иудейского Царства Божьего и «эллинского упования преображения космоса. Сюда входит чаяние преображения и всей человеческой культурной истории» ${ }^{45}$ ). Церковь, писал он, «расширила догму Царства Божьего до универсальной полноты, которою объемлется решительно все. Вот почему мы говорим, что только церковь из всех религиозных систем одна правоспособна решить проблему социальную и государственную, решить религиозно... ${ }^{46}$. Поскольку для Карташева «Царство Израиля» - это «восстановление всего избранного народа с его государством и $[. .$.$] торжеством истинного богопочитания на земле» { }^{47}$, логично, что и Царство Божье Нового Израиля приняло у него образ новой Святой Руси.

\section{Карташев - общественный деятель}

Занявшись общественно-публицистической деятельностью, Карташев время от времени включал элементы апологии единства духа и плоти в свои статьи о церкви и культуре, о взаимосвязи церкви с общественностью и государством и в обсуждение бесперспективности нереформированного православия. Сменив псевдоним Романский на Уральский, он продолжил печататься в «Вопросах жизни» (бывшем «Новом пути», редактировавшемся участниками движения Н.А. Бердяевым и С.Н. Булгаковым) и зарекомендовал себя как церковный оппозиционер. В феврале и марте 1905 г., после Кровавого воскресения, в периодике не утихали нападки на русское духовенство как не предотвратившее манифестацию. И Карташев также связал необходимость реформ в Русской Церкви с ее равнодушием к общественному освободительному движению ${ }^{48}$. Он вывел негативный образ православного епископата, комментируя отклики

43 Там же, с. 174.

44 Там же, с. 173.

45 Там же, с. 173.

46 Там же, с. 174.

${ }^{47}$ Там же, с. 170.

48 Уральский, Начало изерковных откликов на жгучие вопросы настоящего момента, «Вопросы жизни» 1905, № 3, сс. 431-460. 
на революционное движение видных церковных деятелей того времени (епископа Вологодского Никона (Рождественского), архиепископа Финляндского Сергия (Страгородского), митрополита Санкт-Петербургского Антония (Вадковского)). Обращаясь к рядовому духовенству, Карташев писал, что следует не замыкаться на «мистическом служении», но преодолевать «противоестественный разрыв» с «системой социально-экономических отношений» ${ }^{49}$. Так он предлагал пересмотреть позицию православной Церкви в ее отношении к социально-экономической жизни ${ }^{50}$. Причиной невмешательства Русской Церкви в расстрел рабочей манифестации 9 января 1905 г. Карташев назвал «традиционное равнодушие» к бытовой стороне жизни народа. Человеческая культура и общественная жизнь («плоть») также крепко и навечно соединены с духом, как тело и божественный дух в Богочеловеке ${ }^{51}$, и отсутствие в Церкви догмата о «плоти» - причина общественной пассивности духовенства. «Пора подумать духовенству, - писал он, $-[. .$.$] об отношении к плоти и земле» { }^{52}$; безучастное отношение к причинам «общественного зла» делает проповедь пастыря бесплодной ${ }^{53}$. Аполитичный статус Церкви Карташев считал неверным потому, что священник все равно вступает в пределы политики, когда учит народ подчинению властям и законам, так почему, писал он, пастыри не учат и власть подчиняться закону и не раскрывают ее злоупотребления? ${ }^{54}$

В марте 1905 г. «Церковный вестник» напечатал записку группы «32-х» церковных реформаторов о необходимости обновления Русской Церкви. Карташев приветствовал священников-новаторов ${ }^{55}$ как «реформационную партию духовенства» ${ }^{56}$, но отметил ограниченность их возможностей. Он написал, что над ними тяготеют дух и учение православной Церкви, не согласимые со служением земной культуре и общественному благоустройству. По Карташеву, церковные реформаторы получают свое духовное питание из «двух источников», все еще не слитых воедино.

Священники из «реформационной партии», по Карташеву, - необходимая и искомая религиозной интеллигенцией связь с исторической Церковью. «Мы считаем своим приятным долгом отметить, - писал он, $-[\ldots]$ что из лагеря $[. .$.$] цер-$ ковников-гуманистов [...] зазвучали глубоко родственные нам живые голоса» ${ }^{57}$.

\footnotetext{
49 Там же, сc. 438, 439.

50 Там же, с. 440.

51 Там же, с. 453.

52 Там же.

53 Там же, с. 455.

54 Там же.

55 Там же, с. 447.

56 Там же, с. 458.

57 Там же, с. 447.
} 
В подкрепление своей позиции Карташев обращался к статьям реформаторов П.М. Чельцова и К.М. Аггеева, архимандрита Михаила (Семенова), призывал реформаторов к религиозному действию, наставлял. При этом в письмах друзьям признавался, что устал от «попов», а внешние преобразования в Церкви не есть религиозная реформа, искомая интеллигенцией ${ }^{58}$.

Карташев считал, что в России 1905 г. существуют три церковных партии. «На стороне первых - ортодоксия и санкции веков, на стороне вторых [...] пафос жизненной правды и симпатии всего культурного человечества» ${ }^{59}$. Вторые (гуманисты) в меньшинстве, но они могут влиять на ортодоксов. Третья партия колеблющееся среднее, «с бесчисленными оттенками тяготений то вправо, то влево» ${ }^{60}$. Карташев высказал убеждение, что «наступающий перелом» в церковной жизни приведет последних к уяснению принципов двух других партий и поможет им определиться. А после введения «относительной церковной автономии, соборного управления и некоторой свободы богословской мысли» ${ }^{61}$, в Русской Церкви различия проявятся явно, а определит их «специфически русский религиозный вопрос об отношении христианства к жизни и общественности» ${ }^{62}$. «Партийная» система в церкви была для Карташева гарантом ее свободы ${ }^{63}$.

Когда возникла перспектива участвовать в церковно-общественном журнале, Карташев предпочел либеральную печать: он с трудом переносил мысль о возврате в академию и об участии в журнале с церковной тематикой. Карташев писал:

«Церк[овно]-общ[ественный] журнал С.Н. Булгакова и Аггеева Ко будет для меня, по внутренней неприятности, второй академией. И я буду смотреть волком оттуда, пока не найду убежища в органе, верном ценнейшим заветам „новопутейства“”» ${ }^{64}$.

В 1906 г. Философов (вероятно, по своим масонским каналам ${ }^{65}$ ) рекомендовал его в редакцию газеты «Страна». Здесь охотно принимали острые и анти-

${ }^{58}$ Письмо А.В. Карташева Г.И. Чулкову от 17 мая 1905 г., РГАЛИ. Ф. 548, оп. 3, ед. хр. 13, л. 1 об.-2.

59 Уральский, Будущеее иеерковных партий, «Вопросы жизни» 1905, № 3, с. 459.

${ }^{60}$ Там же, с. 459.

${ }^{61}$ Там же.

${ }^{62}$ Там же.

${ }^{63}$ А. Карташев, О партиях в Церкви, «Русское слово» 1906, № 276, с. 2.

${ }^{64}$ Письмо А.В. Карташева Г.И. Чулкову от 17 мая 1905 г., РГАЛИ. Ф. 548, оп. 3, ед. хр. 13, л. 2.

${ }^{65}$ Редакторы газеты М.М. Ковалевский и И.И. Иванюков, как и Д.В. Философов и супруги Мережковские, были русскими масонами. В 1914 г. была создана «ложа», куда вошел и Карташев. См.: Русское масонство. 1731-2000. Энциклопедический словарь, ред. А.И. Серков. Москва, РОССПЭН, 2001, с. 1144. 
клерикальные статьи. Политическая и общественно-экономическая «Страна» (1906-1907) издавалась лидерами Партии демократических реформ. Карташев писал здесь о неготовности Русской Церкви к исторической задаче церковной реформы; поднял и рассмотрел темы: «Церковь и прогресс», «Церковь и реакция», «Церковь и общество», «отделение Церкви от государства», «проблема „культуры“ в православии», «гражданское право на религиозную свободу».

Карташев высмеял в «Стране» сторонников церковного обновления, потому что считал, что синодальная церковь не в состоянии обновиться ${ }^{66}$ в требуемых интеллигенцией параметрах, - социальном и религиозном; она не понимает важности историко-политического момента и не борется с самодержавием. Критика Церкви транслировалась Карташевым и на историческое православие, называемое им «религией смерти» ${ }^{67}$. Карташев не принял выбора Синода оставаться на стороне правительства и царя-помазанника, как того требовала православная этика. Когда в России начались выборы в I Государственную думу, Карташев обратил внимание на осуждение Синодом священников-депутатов, баллотировавшихся по спискам либеральных партий, и выступил в их защиту. Священники избирались в Думу как представители Церкви, но некоторые стали выступать в ней с личным мнением по политическим вопросам, де факто лишая себя тем самым возможности говорить от лица той корпорации, которую представляли в Думе. Карташев показал проблему с моральной стороны и предостерег Русскую Церковь от того, что она может стать в общественном мнении врагом народа.

Наблюдая напряженное ожидание в обществе созыва I Государственной думы, Карташев писал в статье Дума и религиозная свобода ${ }^{68}$, что Россия жаждет свободы и ждет от Думы акта отречения государственной власти от права ограничивать религиозную жизнь и религиозное творчество. Для Карташева религиозная свобода - это не свобода совести и не свобода вероисповедания, но факт публичного права, это свобода культа и свобода пропаганды ${ }^{69}$. Карташев отстаивал право пропаганды глубоких и радикальных перемен в Русской Церкви, и не считал, что ей может навредить широкая религиозная свобода; многочисленные отпадения от православия тогда воспринимались интеллигенцией как очищение Русской Церкви. Как церковный историк, Антон Владимирович не мог не понимать последствий утраты официального статуса господствующей православной Церкви в православной же стране.

\footnotetext{
${ }^{66}$ А. Карташев, O патриархе, «Страна» 1906, № 89, с. 5.

${ }^{67}$ А. Карташев, «Ревность» о Церкви, «Страна» 1906, № 107, с. 6.

${ }^{68}$ А. Карташев, Дума и религиозная свобода, «Страна» 1906, № 57, с. 1.

${ }^{69}$ А. Карташев, К вопросу о религиозной свободе, «Страна» 1906, № 117, с. 1.
} 
В 1908 г. Карташов предлагал статьи в журнал «Вопросы теории и психологии творчества»; в 1908-1910-х гг. публиковался в либеральных «Русском слове» и «Речи», в «Биржевых ведомостях». В 1911 г. сотрудничество в «Русском слове» перешло на постоянную основу. Это была еженедельная газета, выходившая по всей России, печататься в ней было выгодно и престижно. По договору Карташев должен был просматривать все пересылаемое ему редакцией и еженедельно готовить свои и чужие статьи церковной тематики. Он предполагал привлечь в качестве сотрудников профессоров духовных академий («под псевдонимом, за моим прикрытием», - писал он ${ }^{70}$ ) и обещал свежую информацию из «синодальных сфер». «Хочется, - писал он о Русской Церкви, воздействовать на нее нравственно-обязательными для нее аргументами», но при этом задействовать «идеи богословско-метафизические или... религиознопсихологические» ${ }^{71}$.

\section{На посту председателя Петербургского (Петроградского) РФО}

К организации ПРФО в 1907 г. А.В. Карташев отнесся скептически, понимая, что возрождение Религиозно-философских собраний (1901-1903), куда приходило для бесед с интеллигенцией ученое монашество и высшее духовенство, невозможно. Но учредители ПРФО С.Н. Булгаков, Н.А. Бердяев и С.А. Алексеев (Аскольдов) «рвались в бой» ${ }^{72}$, а из Парижа настаивали Д.С. и З.Н. Мережковские. Карташев поддержал открытие ПРФО, выступив с приветственной речью. В ноябре 1909 г. фракция Мережковского получила большинство в совете и прерогативу выбирать доклады. Как один из лидеров движения, Карташев вошел в совет ПРФО, но редко бывал на собраниях. ПРФО занималось литературными темами, его активность в сезон 1911/12 гг. дошла до почти «мертвой стадии» (три заседания за сезон). Нужно было искать выход из положения. В 1911 г. Антону Владимировичу исполнилось 36 лет. Он был известным критиком официальной Церкви и пользовался уважением как профессор Высших женских курсов. Мистический догматизм Мережковского уже представлялся ему столь же стеснявшим религиозную свободу, как и догматизм церковный. Он чувствовал себя вполне самодостаточным, верным своим убеждениям человеком и предпринял попытку вести среди действительных членов

${ }^{70}$ Цит. по: С.П. Бычков, А. В. Карташев в «Русском слове» в 1911-1917 г2. Переписка с издателем, «Вестник Омского университета. Серия „Исторические науки“» 2019, № 3, с. 249.

${ }^{71}$ Там же.

${ }^{72}$ Там же. 
ПРФО религиозно-просветительские занятия. Согласно дневнику С.П. Каблукова, целью занятий было «окончательное и полное выяснение [...] отношения к православной Церкви» ${ }^{73}$, участники должны были познакомиться с канонами, догматикой и историей православия, предполагалось изучение ряда богословских книг, в том числе, символической книги Русской Церкви Православное исповедание кафолической и апостольской церкви восточной, Догматического богословия митрополита Московского Макария (Булгакова). Судя по подбору литературы, Антон Владимирович хотел дать своему ближайшему кругу начатки церковного образования. На первое занятие на квартире Карташева 29 октября 1911 г. были приглашены супруги Д.С. и 3.Н. Мережковские, А.А. Мейер, Т.Н. Гиппиус, С.П. Каблуков. Мережковские и Мейер к идее изучать основы православия отнеслись равнодушно, Карташев оказался перед дилеммой: превратить эти занятия в личные беседы или попробовать заинтересовать вторичный круг неохристиан. Видимо, из карташевских богословских чтений ничего не вышло, больше С.П. Каблуков о них не упоминал. Но в 1912 г. совет предложил Карташеву должность председателя.

Первое полугодие 1913 г. Карташев исполнял обязанности председателя ПРФО. Избрание и утверждение его кандидатуры состоялось на общем собрании 29 октября 1913 г. Его руководство придало работе Общества системность и идейную направленность. Общество от литературных тем повернуло к религиозным, были возрождены дискуссии о взаимоотношениях Церкви и государства, о Царстве Божием на земле как новом порядке бытия в истории. Карташев лично занимался организацией каждого собрания, тщательно готовил прения, обговаривая с оппонентами их речи. Это требовало много времени, и Карташев стал отказываться от журналистской деятельности. К тому же было свернуто издание всех периодических журналов религиозного движения, ряды движения покинули С.Н. Булгаков, С.П. Свенцицкий, В.Ф. Эрн, из церковных реформаторов остались единицы, а религиозная интеллигенция оспаривала метафизику НРС, что вызвало обособление мережковской «троицы» от остальных.

За год председательства в ПРФО Карташева число членов ПРФО в 19131914 гг. перевалило за тысячу, это были люди разных религиозных конфессий. 14 ноября 1913 г. совет ПРФО, собравшись узким кругом неохристиан, пришел к решению лишить членства в ПРФО давнего друга и доверительного корреспондента Карташева - В.В. Розанова. Попав меж двух огней - писателем, с которым предстояло разорвать дружеские связи, и советом ПРФО, которому из-за границы поступил таинственный «запрос» о том, почему Общество не реагирует

${ }^{73}$ А.А. Ермичев, Религиозно-философское общество в Петербурге (1907-1917): Хроника заседаний, Санкт-Петербург, Издательство Санкт-Петербургского университета, 2007, с. 119. 
на статьи Розанова по поводу «дела» Менахема Менделя Бейлиса, Антон Владимирович предпочел отнестись к ситуации формально, как официальный председатель, действующий в соответствии с уставом Общества, и провести исключение голосованием. Но первая попытка провести решение совета через общее собрание провалилась: большинство ПРФО выступило против.

Карташев, не терпевший черносотенства, возмущенно воспринял и отношение российской общественности к обвиненному в ритуальном убийстве M.М. Бейлису. Чтобы выступить аргументированно, он обратился к текстам Талмуда, и стал писать статьи, показывавшие бездоказательность обвинений в адрес евреев ${ }^{74}$. Документов, которые свидетельствовали бы о душевных колебаниях Карташева по розановскому вопросу, не сохранилось, но председательство на собрании, в ходе которого обсуждалось решение совета об исключении писателя, он передал М.И. Туган-Барановскому. Короткие официальные письма за подписью Карташева, извещавшие Розанова о постановлении совета ПРФО, а затем и о решении (принятом на повторном собрании Общества), это все, что сохранилось на этот счет в розановском архивном фонде ${ }^{75}$.

26 января 1914 г. Карташев произнес 11 -страничную эмоциональную речь ${ }^{76}$ после того, как действительные члены ПРФО и даже члены-соревнователи воспротивились исключению писателя. В ней он перенес вину с совета, инициировавшего исключение, на самого Розанова, якобы спровоцировавшего определенное к себе отношение - тем, что он а) принципиально бездействовал в совете, и б) сам давно публично заявил о своем выходе из ПРФО, напечатав 17 января 1909 г. письмо в газете «Новое время»; в) игнорировал неоднократные приглашения в ПРФО для обсуждения вопроса об исключении. По Карташеву, совет предлагал Обществу закрепить совершившийся факт отпадения от ПРФО.

Речь Карташева в значительной мере была откровением о нем самом и защитой ПРФО. Та ее часть, которая была посвящена Розанову, состояла из нескольких позиций: а) ПРФО по всем текущим показателям не является полуофициальными ПФРС, а имеет статус общественной организации с новым кредо и новым подбором членов; б) Розанов не просто вышел из совета ПРФО, он - «безотчетный» писатель, любящий только поговорить («писатель-говоритель» ${ }^{77}$ ), он почувствовал, что далее «сыпать безответственно словами» не получится; в) ПРФО «влилось в общий состав русской интеллигентской, общественной жизни»

\footnotetext{
${ }^{74}$ А. Карташев, Разоблачитель или поддельватель?, «Русское слово» 1913, № 239, с. 2.

75 Письмо А.В. Карташева В.В. Розанову от 5 марта 1903 г., РГАЛИ. Ф. 419, оп. 1, ед. хр. 22, лл. 1-6.

${ }^{76}$ Религиозно-философское общество..., указ. соч., т. 2, сс. 441-451.

${ }^{77}$ Там же, с. 443.
} 
(стало «религиозно-общественным») ${ }^{78}$, и потому руководится критерием «общественной порядочности» ${ }^{79}$, которой Розанов не удовлетворяет. Четвертой позицией (г) было обвинение, брошенное Карташевым тем, кто защищал Розанова от исключения. По мнению Карташева, они поступили непорядочно, сбросив ответственность за Розанова на ПРФО, тогда как сами, будучи членами общественных организаций (редакций журналов и газет), «постарались очиститься от него» ${ }^{80}$. Следующей была позиция религиозная: д) «общественная непорядочность Розанова - есть верный симптом и символ иной, [...] враждебной правде Христовой, религиозной силы» ${ }^{81}$. Готово ли ПРФО быть в общественном мнении «смешанным» с Розановым в одну «культурно-пикантную кашу» ${ }^{82}$, - спрашивал Карташев. Последней позицией (е) стал акцент на то, что ПРФО выступает за религиозное освобождение человека и освобождение «религии от оков», и освобождаясь от Розанова, оно тем самым борется с «культурными и религиозными соблазнами [...] националистического и церковного лагеря» ${ }^{83}$. Карташев суммировал: «совершенно не важно, в какую юридическую форму [можно - И.В.] облечь наше разделение с Розановым - важно лишь провозгласить, что мы не с его лагерем» ${ }^{84}$. Таким образом, не присоединившись к не менее известным и уважаемым общественным деятелям, не соглашавшимся с исключением Розанова, Карташев занял точку зрения неохристианского круга.

ПРФО продолжило свою работу под руководством Карташева вплоть до 1917 г., занимаясь вопросами религии и ее значения для государства и церковной реформы, неохристиане предлагали смотреть на близящуюся революцию как силу разрушительную, но допустимую и необходимую для развития жизни наций и государств. Для Карташева связь с общественностью оставалась первейшей обязанностью Церкви, он был убежден, что должна произойти встреча церковного сознания с гуманистическими общественными представлениями, «нажитыми вне церковной ограды», и гуманитарное мировоззрение при встрече с традиционной формой христианства обогатит последнее. Без этого, по Карташеву, историческое христианство оставалось неполным. «Разрешить проблему о церкви, не только историческую, а и религиозную, мистическую, социально-философскую, - говорил он 15 марта 1915 г., - большая задача» ${ }^{85}$. За год до Февральской революции 1917 г. эта задача была откорректирована.

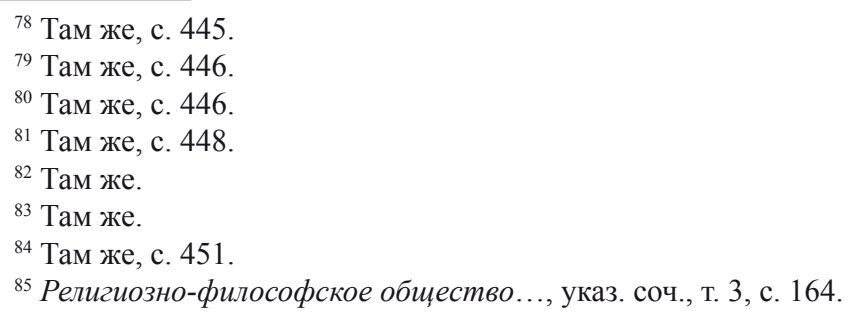


Наступал новый этап российской политической истории, который возрождал в теоретиках НРС надежду на такую свободу, которая зажжет и «новый догматический свет ${ }^{86}$ в Русской Церкви, приведет к такому церковному христианству, которое возьмет на себя все проблемы человеческого духа и человеческого общества ${ }^{87}$. Следовало обсудить исторические возможности и наметить возможные будущие пути. Карташев подготовил большую речь в ПРФО, которую впоследствии назвал «трактатом».

В феврале 1916 г. члены IV Государственной думы принялись за решение вопросов, связанных с правами прихода. Внешняя, административного типа, реформа всегда была неинтересна неохристианам. Что религиозного в том, чтобы

«организовать приход на началах юридического лица, в том, чтобы реформировать консисторию и бракоразводный процесс, чтобы реорганизовать Синод, урегулировать положение обер-прокурора, учредить патриаршество, снять государственный запрет с функции соборности» ${ }^{88}$ ?

Такой была традиционная реакция неохристиан на планировавшиеся Церковью реформы. Но 28 февраля 1916 г. на закрытом собрании ПРФО Карташев провозгласил курс на одобрение внешних или административных реформ. Они были обозначены как полуполитические. Было подчеркнуто и то, что церковная реформа - это дело людей политически прозревших.

Выступление Карташева издали книжкой с заглавием Реформа, реформация и исполнение Церкви, многие воспринимают ее плохо структурированное содержание как отказ Карташева от идеи церковного реформирования, но это не так. Неслучайно она послужила в эмиграции поводом к письменному объяснению Карташева по запросу митрополита Евлогия (Георгиевского). Карташев ставил задачу охарактеризовать известные истории церковные реформы, аргументировать предпочтение одних и неприятие других, и определить исходную точку в российских условиях.

Обличая цивилизацию в том, что она ищет «социального устроения людей без Бога» ${ }^{89}$, Карташев наметил три пути устранения этого недостатка: политический, реформационный и религиозный. Церковная реформа, говорил он, «нам рисуется в первой стадии вопросом политическим» ${ }^{90}$. «Если общая свобода даст свободу и Церкви, то да будет благословенен ее приход» ${ }^{91},-$ цитиро-

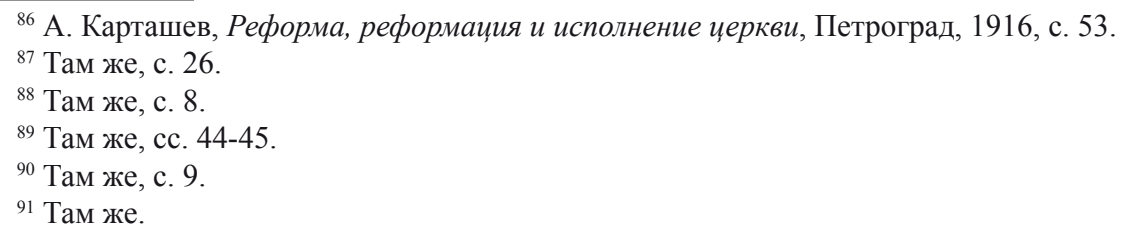


вал он фразу из парламентской речи В.Н. Львова, и заключил, что история показывает целесообразность церковной реформы как неотделимой части общей политической реформы. Когда таким образом «уста» Церкви будут «распечатаны», а «ноги и руки развязаны», тогда и будет «ясно, каков ее религиозный предел». Этот путь, считал он, изменит в положительную сторону отношение к вере и положение Церкви в государстве.

Предвидя опасения церковного раскола в «политически освобожденной» Церкви, Карташев считал, что раскол маловероятен: церковная масса инертна ${ }^{92}$, после старообрядчества расколы в Русской Церкви стали невозможны, так как запасы «церковной православной энергии» оскудели. Из «нового течения составится покровительствуемое обновленной государственной властью большинство, господствующая Церковь, которая и вступит на умеренно-либеральный путь» ${ }^{93}$, писал он. Но что будет на этом политическом пути с православием? Дело не в его сосуществовании с государством, дело в теократическом призвании православия ${ }^{94}$, оно «дорожит [...] связью с религиозным носителем власти государственной», это следствие его религиозного инстинкта и теократических задач церкви ${ }^{95}$. Русскую Церковь можно внешними политическими реформами разлучить с ее «теократическим стилем», но это означало бы сдать ее в архив ${ }^{96}$. Карташев предположил, что среди «государственных церковников [...] возникнет новое церковное течение» - чутких к запросам жизни людей, которые, «оказавшись в обстановке освобожденной Церкви [...] будут искать [...] более демократических путей воплощения теократического идеала» ${ }^{97}$.

Внешняя реформа освободит Церковь, но не будет «глубоким внутренним обновлением ее по существу» ${ }^{98}$. Для этого нужен путь религиозный. Религиозное творчество в Церкви приведет к такого рода начинаниям, которые перейдут «грани простой реформы» и поставят Церковь на путь реформации. С другой стороны, рационализация догматов может вести к

«величайшему обеднению Церкви; упразднение ее теократической души может выбросить за борт весь запас социальных заданий христианства. Тогда получится умиротворенная, очень удобная для светской безрелигиозной культуры, национальная Церковь как одна из ничтожных восточных Церквей, навеки бесплодная» ${ }^{99}$.

\footnotetext{
92 Там же, с. 16.

${ }_{93}$ Там же, с. 13.

94 Там же, с. 14.

${ }_{95}^{5}$ Там же, с. 15.

${ }^{96}$ Там же, с. 16.

${ }^{97}$ Там же, с. 18.

${ }_{98}$ Там же, с. 17.

${ }^{99}$ Там же.
} 
Карташев подчеркивал, что он не принимает те исторические формы, в которые вылилась Реформация в католицизме и считает, что будущее движение обязано «разойтись с [...] взглядом на протестантскую форму христианства как на высшую и дающую разрешение современным запросам человечества», но и не должно испытывать «того страха», какой вызывает протестантизм у «консерваторов ${ }^{100}$.

Он подвел к мысли, что русская Реформация должна пройти срединным и самобытным путем, быть глубже, религиознее, духовнее. Главная ее задача это сохранение идеи церкви как коллектива с иерархической структурой, вершиной которой является Христос. «Мы выдвигаем идею церкви», в догмате о которой должны сойтись все пути к разрешению вопросов человеческого общежития и космоса ${ }^{101}$, к преодолению разрыва между церковью и жизнью, для чего надо поставить эти вопросы как вопросы религиозной совести, или веры $^{102}$.

Его речь показала, что за годы участия в движении он сохранил надежду на историческую Церковь, но остался убежден в необходимости реформирования ее новым отношением к «плоти»; что к 1917 г. Карташев имел представления о том, как должен протекать этот процесс, в этом плане вполне логично назначение его через год товарищем обер-прокурора В.Н. Львова (Львов был близко знаком неохристианам), а затем и министром вероисповеданий Временного правительства.

В 1901-1916 гг. А.В. Карташев прошел путь от доцента духовной академии и церковного либерала до убежденного реформатора православия, в конце этого пути он был готов содействовать внешним реформам в исторической Русской Церкви, так как верил, что реформация даст ей второе дыхание, сделает центром жизни новой России.

\section{Источники}

Письмо А.В. Карташева В.И. Иванову от 7 апреля 1911 г., Научно-исследовательский отдел рукописей Российской государственной библиотеки (НИОР РГБ). Ф. 109, к. 27, ед. хр. 20, лл. 1-4 об.

Письмо А.В. Карташева В.В. Розанову от 5 марта 1903 г., Российский государственный архив литературы и искусства (РГАЛИ). Ф. 419, оп. 1, ед. хр. 22, лл. 1-6, ед. 482, лл. 1-1 об.

\footnotetext{
100 Там же, с. 25.

${ }^{101}$ Там же, сс. 27-28.

102 Там же, с. 47.
} 
Письмо А.В. Карташева Г.И. Чулкову от 17 мая 1905 г., Российский государственный архив литературы и искусства (РГАЛИ). Ф. 548, оп. 3, ед. хр. 13, л. 1.

Записки Петербургских религиозно-философских собраний (1901-1903 г2.), общ. ред. С.М. Половинкина, Москва, Республика, 2005, 543 с.

Карташев А., Был ли апостол Андрей на Руси?, «Христианское чтение» 1907, № 6, сc. 83-95.

Карташев А., Дума и религиозная свобода, «Страна» 1906, № 57, с. 1.

Карташев А., К вопросу о религиозной свободе, «Страна» 1906, № 117, с. 1.

Карташев А., Краткий историко-критический очерк систематической обработки русской церковной истории, «Христианское чтение» 1903, № 6, сс. 909-922; № 7, сc. 77-93.

Карташев А., О партиях в Церкви, «Русское слово» 1906, № 276, с. 2.

Карташев А., O патриархе, «Страна» 1906, № 89, с. 5.

Карташев А., Разоблачитель или поддельватель?, «Русское слово» 1913, № 239, c. 2.

Карташев А., «Ревность» о Церкви, «Страна» 1906, № 107, с. 6.

Карташев А., Реформа, реформация и исполнение Церкви, Петроград, Корабль, 1916, 66 c.

Карташев А., Христианство на Руси в период догосударственный, «Христианское чтение» 1908, № 5, сс. 763-778.

Религиозно-философское общество в Санкт-Петербурге (Петрограде): История в материалах и документах. 1907-1917, в 3 m., сост., подгот. текста, вступ. ст. и примеч. О.Т. Ермишина, О.А. Коростелева, Л.В. Хачатурян и др., Москва, Русский путь, 2009.

Романский Т., Не все же, «Новый путь» 1903, № 6, сс. 269-276.

Уральский, Будущеее иеекковных партий, «Вопросы жизни» 1905, № 3, сс. 431460.

Pachmuss T., Intellect and Ideas in Action: Selected Correspondence of Zinaida Hippius, München, Fink, 1972, 784 cc.

\section{Литература}

Антощенко А.В., «Евразия» или «Святая Русь»? Российские эмигранты «первой волныл» в поисках исторического самосознания: дис. д-ра ист. наук, С.-Петербургский государственный университет, Санкт-Петербург, 2003, $432 \mathrm{cc}$. 
Бычков С.П., А.В. Карташев в «Русском слове» в 1911-1917 г2. Переписка с издателем, «Вестник Омского университета. Серия “Исторические науки”» 2019, № 3, сс. 245-254.

Бычков С.П., О проблемах исследования первого периода жизни русского изерковного историка A.B. Карташева, «Вестник Омского университета» 2018, № 3 (19), сс. 228-233.

Бычков С.П., «Очерки по истории русской цчеркви» А.В. Карташева в оченке современников, [в:] Омские научные чтения 2020: Материаль Четвертой Всероссийской научной конференции, Омск, Омский государственный университет им. Ф.М. Достоевского, 2020, сс. 1298-1303.

Воронцова И.В., Русская религиозно-философская мысль в начале ХХ века, Москва, Издательство Православного Свято-Тихоновского гуманитарного университета, 2008, 424 сc.

Воронцова И.В., Тематика статей А.В. Карташева в газете “Страна» 19061907 г2. в свете программных аспектов движения религиозной интеллигенциизацеерковнуюреформу, «Вестник Православного Свято-Тихоновского гуманитарного университета» 2019 (II), № 5-6, сс. 11-24.

Воронцова И.В., Револючия и религия в дискуссии 1906-1914 годов Д.С. Мережковского, Н.А. Бердяева и П.Б. Струве и других, «Религиоведение» 2011, № 4, cс. 28-39.

Ермичев А.А., Религиозно-философское общуество в Петербурге (1907-1917): Хроника заседаний, Санкт-Петербург, Издательство Санкт-Петербургского университета, 2007, $323 \mathrm{cc.}$

Золаев А.Л., Исторические воззрения А.В. Карташева и историография русского зарубежья: дисс. канд. филос. наук, Российский университет дружбы народов, Москва, 2005, $181 \mathrm{cc.}$

Переписка Д.С. Мережковского с В.И. Ивановым, публикация и комментарии М. Цимборской-Лебоды и Н.А. Богомолова, [в:] W kraju i na obczyźnie. Literatura rosyjska XX wieku. Studia Rossica VII, ред. W. Skrunda, Warszawa, Wydawnictwo «Studia Rossica», 1999, cc. 81-91.

Пешков А.А., Философия истории П.Н. Милюкова и А.В. Карташева: сравнительный анализ: дисс. канд. филос. наук, Нижегородский государственный педагогический университет, Нижний Новгород, 2014, 156 сс.

Русское масонство. 1731-2000. Энииклопедический словарь, ред. А.И. Серков, Москва, РОССПЭН, 2001, 1224 сс.

Феофан Затворник, Начертание христианского нравоучения, Москва, Лепта, 2003.

Цимборска-Лебода М., Богомолов Н. А., К проблеме «Мережковский и Вячеслав Иванов», [в:] W kraju i na obczyźnie. Literatura rosyjska XX wieku. Studia 
Rossica VII, ред. W. Skrunda, Warszawa, Wydawnictwo «Studia Rossica», 1999, cc. $65-80$.

\section{References}

Primary sources

Pis'mo A. V. Kartasheva V. I. Ivanovu ot 7 aprelia 1911 g. [A. Kartashev's Letter to V. Ivanov, 7 April 1911]. Nauchno-issledovatel'skii otdel rukopisei Rossiiskoi gosudarstvennoi biblioteki (NIOR RGB) [The Manuscripts Department of the National Library of Russia], coll. 109, b. 27, item 20, pp. 1-4 v.

Pis'mo A. V. Kartasheva V. V. Rozanovu ot 5 marta 1903 g. [A. Kartashev's Letter to V. Rozanov, 5 March 1903]. Rossiiskii gosudarstvennyi arkhiv literatury i iskusstva (RGALI) [Russian State Archive of Literature and Art], coll. 419, aids 1 , item. 22, pp. 1-6, item 482, p. 1 v.

Pis'mo A. V. Kartasheva G. I. Chulkovu ot 17 maia 1905 g. [A. Kartashev's Letter to G. Chulkov, 17 May 1905]. Rossiiskii gosudarstvennyi arkhiv literatury i iskusstva (RGALI) [Russian State Archive of Literature and Art], coll. 548, aids 3, item 13, p. 1.

Ermishina O.T., Korosteleva O.A., Khachaturian L.V. et al. eds., Religiozno-filosofskoe obshchestvo $v$ Sankt-Peterburge (Petrograde): Istoriia v materialakh i dokumentakh. 1907-1917, v 3 t. [Religious and Philosophical Society in St. Petersburg (Petrograd): History in Materials and Documents 1907-1917, in 3 Volumes], Moscow, Russkii put' Publ., 2009.

Kartashev A., Byl li apostol Andrei na Rusi? [Was there Apostle Andrew in Russia?], "Christian Reading" 1907, no. 6, pp. 83-95.

Kartashev A., Duma i religioznaia svoboda [The State Duma and Religious Freedom], "Strana" 1906, no. 57, p. 1.

Kartashev A., K voprosu o religioznoi svobode [Question of Religious Freedom], "Strana" 1906, no. 117, p. 1.

Kartashev A., Khristianstvo na Rusi v period dogosudarstvennyi [Christianity in Russia in the Pre-State Period], "Christian Reading" 1908, no. 5, pp.763-778.

Kartashev A., Kratkii istoriko-kriticheskii ocherk sistematicheskoi obrabotki russkoi tserkovnoi istorii [A Brief Historical and Critical Essay on the Systematisation of Russian Church History], "Christian Reading" 1903, no. 6, pp. 909-922; no. 7, pp. 77-93.

Kartashev A., O partiiakh v Tserkvi [About Parties in the Church], "Russkoe slovo" 1906, no. 276, p. 2 
Kartashev A., O patriarkhe [About the Patriarch], "Strana" 1906, no. 89, p. 5.

Kartashev A., Razoblachitel' ili poddelyvatel'? [Unmasker or Faker?], "Russkoe slovo" 1913, no. 239, p. 2.

Kartashev A., Reforma, reformatsiia i ispolnenie Tserkvi [Reform, Reformation and Fulfillment of the Church], Petrograd, Korabl' Publ., 1916, 66 pp.

Kartashev A., "Revnost'” o Cerkvi [Zeal about the Church], "Strana" 1906, no. 107, p. 6.

Pachmuss T., Intellect and Ideas in Action: Selected Correspondence of Zinaida Hippius, München, Fink, 1972, 784 pp.

Polovinkin S.M. ed., Zapiski Peterburgskikh religiozno-filosofskikh sobranii (19011903 gg.) [Notes of St. Petersburg Religious and Philosophical Meetings (19011903)], Moscow, Respublika Publ., 2005, 543 pp.

Romanskii T., Ne vse zhe [Not all of them], "Novyj put"' 1903, no. 6, pp. 269-276. Ural'skii, Budushchee tserkovnykh partii [Future of the Church Parties], "Voprosy zhizni" 1905, no. 3, pp. 431-460.

Secondary sources

Antoshchenko A.V., "Evraziia" ili "Sviataia Rus"”? Rossiiskie emigranty "pervoi volny" v poiskakh istoricheskogo samosoznaniia: dis. d-ra ist. nauk ["Eurasia" or "Holy Russia"? Russian Emigrants of the First Wave in Search of Historical Self-Awareness. Dr. hist. sci. diss.], Saint Petersburg State University, St. Petersburg, 2003, 432 pp.

Bychkov S.P., A.V. Kartashev v "Russkom slove" v 1911-1917 gg. Perepiska s izdatelem [A. Kartashev in the "Russian Word" in 1911-1917. Correspondence with the Publisher], "Herald Of Omsk University. Series "Historical Studies"” 2019, no. 3, pp. 245-254.

Bychkov S.P., O problemakh issledovaniia pervogo perioda zhizni russkogo tserkovnogo istorika A.V. Kartasheva [On the Problems Arising When Researching A. Kartashev's, a Russian Church Historian, First Period of Life], "Herald Of Omsk University" 2018, no. 3 (19), pp. 228-233.

Bychkov S.P., "Ocherki po istorii russkoi tserkvi" A.V. Kartasheva v otsenke sovremennikov [A. Kartashev's "Lectures on the History of the Russian Church" Evaluated by His Contemporaries], [in:] Omskie nauchnye chteniia 2020: Materialy Chetvertoi Vserossiiskoi nauchnoi konferentsii, Omsk, Dostoevsky Omsk State University, 2020, pp. 1298-1303.

Cymborska-Leboda M., Bogomolov N.A., K probleme "Merezhkovskii i Viacheslav Ivanov" [On "Merezhkovsky and Vyacheslav Ivanov's" Issue], [in:] W kraju i na obczyźnie. Literatura rosyjska XX wieku. Studia Rossica VII, Skrunda W. (Ed.), Warszawa, Studia Rossica Publ., 1999, pp. 65-80. 
Cymborska-Leboda M., Bogomolov N.A. (Eds.), Perepiska D. S. Merezhkovskogo s V.I. Ivanovym [Correspondence Between D. Merezhkovsky and V. Ivanov, [in:] W kraju i na obczyźnie. Literatura rosyjska XX wieku. Studia Rossica VII, Skrunda W. (Ed.), Warszawa, Studia Rossica Publ., 1999, pp. 81-91.

Ermichev A.A., Religiozno-filosofskoe obshchestvo v Peterburge (1907-1917):

Khronika zasedanii [St. Petersburg's Religious-Philosophical Society in the Years 1907-1917: Chronicle of Meetings], St. Petersburg, St. Petersburg University Publ. House, 2007, 323 pp.

Peshkov A.A., Filosofiia istorii P.N. Miliukova i A.V. Kartasheva: sravnitel'nyi analiz: diss. kand. filos. nauk [P. Milyukov's and A. Kartashev's Philosophy of History: Comparative Analysis. Cand. phil. sci. diss.], Minin Nizhny Novgorod State Pedagogical University, Nizhny Novgorod, 2014, 156 pp.

Serkov A.I. ed., Russkoe masonstvo. 1731-2000. Entsiklopedicheskii slovar' [Russian Masonry in the Years 1731-2000. Encyklopaedia], Moscow, ROSSPEN Publ., 2001, 1224 pp.

Theophan the Recluse, Nachertanie khristianskogo nravoucheniia [The Outline of Christian Teachings], Moscow, Lepta Kniga Publ., 2003.

Vorontsova I.V., Revoliutsiia i religiia v diskussii 1906-1914 godov D.S. Merezhkovskogo, N.A. Berdiaeva i P.B. Struve i drugikh [Revolution and Religion As Depicted in Discussions of the Years 1906-1914 by D. Merezhkovsky, N. Berdyaev, P. Struve and Others], "Religiovedenie" 2011, no. 4, pp. 28-39.

Vorontsova I.V., Russkaia religiozno-filosofskaia mysl'v nachale XX veka [Russian Religious and Philosophical Thought at the Beginning of the XX century], Moscow, St. Tikhon's Orthodox University Publ. House, 2008, 424 pp.

Voroncova I.V., Tematika statej A.V. Kartasheva v gazete "Strana" 1906-1907 gg. $v$ svete programmnyh aspektov dvizheniia religioznoi intelligencii za cerkovnuiu reformu [The Subject of A. Kartashev's Articles in the Newspaper "Strana" in 1906-1907 in the Light of the Program Aspects of the Movement of Religious Intelligentsia Supporting Church Reform], "St. Tikhon's University Review" 2019 (II), no. 5-6, pp. 11-24.

Zolaev A.L., Istoricheskie vozzreniia A.V. Kartasheva i istoriografiia russkogo zarubezh'ia: diss. kand. filos. nauk [A. Kartashev's Historical Views and Historiography of the Russian Diaspora. Cand. phil. sci. diss.], RUDN University, Moscow, 2005, 180 pp. 
